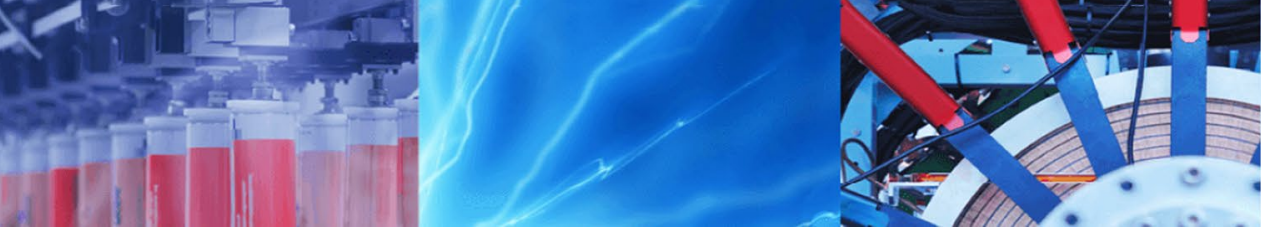

Research Article

\title{
Anticoagulant activity of partially purified chitinase produced by Citrobacter freundii str. nov. haritD11 by fermentation of wheat bran coupled with fish scales
}

\author{
Haritha Meruvu ${ }^{1}$ (D) Hari Bhanu Teresa Meruvu²
}

(c) Springer Nature Switzerland AG 2018

\begin{abstract}
Solid phase fermentation of wheat bran coupled with powdered fish scales could yield chitinase using a novel Citrobacter strain. The fermentation conditions are optimized conventionally ( $84.14 \mathrm{U} / \mathrm{gds})$ and statistically $(94.3 \mathrm{U} / \mathrm{gds})$. The partially purified chitinase had a specific activity of $53.41 \mathrm{U} / \mathrm{mg}$ with optimal activity at $\mathrm{pH} 8.5$ and $50^{\circ} \mathrm{C}$, it was stable at $7.5-10 \mathrm{pH}$ range for $24 \mathrm{~h}$ with more than $80 \%$ stability at $45-60^{\circ} \mathrm{C}$, and the $\mathrm{Km}$ value of chitinase with swollen chitin (substrate) is $8.11 \mathrm{mg} / \mathrm{ml}$ with a $V_{\max }$ of $2.43 \mathrm{mmol} \mathrm{h}^{-1} \mathrm{ml}^{-1}$. The partially purified enzyme was halotolerant showing maximum activity and stability up to $10 \%$ of $\mathrm{Nacl}$, also possessing potential anticoagulant activity. This is the first report to date elucidating the production of halotolerant chitinase from wheat bran supplemented with fish scales using Citrobacter freundii haritD11 and its application as an anticoagulant agent and notable tolerance to heavy metal ions.
\end{abstract}

Keywords Chitinase $\cdot$ Wheat bran · Citrobacter freundii haritD11 $\cdot$ Purification · Anticoagulant · Antimicrobial

\section{Objectives and background}

In our prior works which pivoted around Citrobacter freundii str. nov. haritD11, isolation and identification of $C$. freundii haritD11, its fermentation using shrimp waste, production, purification and characterization subterfuges of chitinase were evidently reported [20-22, 24]. However, this is the first report to date elucidating the production of chitinase through solid state fermentation of wheat bran supplemented with fish scales using $C$. freundii haritD11, its partial purification, characterization and constituent anticoagulant activity. This paper also re-emphasizes that this novel strain C. freundii haritD 11 could be commercially exploited to use its enzyme preparations both in crude and purified forms as anticoagulant agents. Moreover, until now there is no known report on chitinase production from Citrobacter freundii through fermentation of wheat bran supplemented with fish scales and estimation of possible anticoagulant, antibiotic and metal resistance properties of obtained chitinase.

\section{Introduction}

As feedstock in solid state fermentation (SSF), a plethora of solid wastes such as husks of rice, wheat, green/black/ red grams, cereal brans, sugarcane bagasse, vegetable and fruit peels, and chitinous wastes such as shrimp/crab shells and fish scales can be deployed [22,33]. Agroindustrial wastes such as wheat/rice bran are used by microorganisms as finicky substrates in SSF for production of industrial enzymes and biopharmaceuticals due to their porous structure amenable for growth and capacity to hold requisite moisture [8]. Production of a multitude of industrial enzymes such as cellulases and xylanases [29], amylases $[2,23]$, proteases [19] using SSF and agroindustrial wastes

\footnotetext{
$\triangle$ Haritha Meruvu, dr.hari299@gmail.com | 'Department of Chemical Engineering, Center for Biotechnology, AU College of Engineering, Andhra University, Visakhapatnam, Andhra Pradesh 530018, India. ${ }^{2}$ Andhra Medical College, King George Hospital, Visakhapatnam, Andhra Pradesh, 530002, India.
} 
has been reported by earlier researchers. Fish scales are chitin loaded and can be used as substratum to produce chitinolytic microbial enzymes $[11,14]$. Chitin production in vertebrates by means of chitin synthase has also been reported [30]. Wheat bran supplemented with chitinous sources can be used as a substrate for chitinase production [5].

Marine microbes are reputed for their immense biodiversity and production of different kinds of enzymes and biochemicals of industrial grade $[3,17]$. Screening and assessment of biochemical requirements of a microorganism for enzyme production is a must for bioprocess development during SSF for chitinase production; hence in this report SSF is carried out using wheat and conventional optimization studies through one-variable-at-a-time (OVAT) approach followed by statistical optimization using Box-Behnken method [6] are conducted for monitoring chitinase controlling parameters. Citrobacter freundii strain novel haritD11 (GenBank accession: KC344791) with chitinolytic activity isolated from marine sediment is used as inoculum for SSF studies and the chief substrate was wheat bran, procured from a local flour mill, were used throughout the experimentation. The chitinase produced is partially purified through ammonium sulfate precipitation, dialysis, gel filtration and characterized for its various properties.

\section{Material and method}

\subsection{Chitinase activity assay}

$0.1 \mathrm{ml}$ of chitinase to be assayed is mixed with $0.1 \mathrm{ml}$ of substrate solution ( $10 \%$ colloidal chitin in $0.2 \mathrm{M}$ phosphate buffer, $\mathrm{pH}$ 8.0) and incubated for an hour at $35^{\circ} \mathrm{C}$. Amount of reducing sugar released is measured by DNS method [25] at $540 \mathrm{~nm}$ using $\mathrm{N}$-acetyl-D glucosamine standard. One unit of chitinase activity is defined as the amount of enzyme producing $1 \mu \mathrm{mol}$ of GlcNAc per hour at specified assay conditions [3].

\subsection{Microorganism and fermentation studies}

Citrobacter freundii haritD11 (GenBank Accession number KC344791) was isolated from a marine sediment sample taken from beach area of the Bay of Bengal sea coast, India ( $17^{\circ} 31^{\prime} 51^{\prime \prime}$ north latitude and $83^{\circ} 4^{\prime} 53^{\prime \prime}$ east longitude), and is used as fermentation inoculum throughout. The organism's biochemical and molecular taxonomy were reported in our previous report [22]. Its chitinolytic activity is visualized by streaking over minimal salt (MS)-chitin agar plate containing $0.5 \% \mathrm{w} / \mathrm{v}$ colloidal chitin with MS medium [12], incubated and observed for $72 \mathrm{~h}$ at $30^{\circ} \mathrm{C}$. The strain showed a striking zone of clearance of nearly $0.62 \mathrm{~cm}$ after $24 \mathrm{~h}$. It is maintained on yeast extract-malt extract agar slants and subcultured every 30 days [18]. Initial fermentation conditions for chitinase production are $24 \mathrm{~h}$ incubation at $30^{\circ} \mathrm{C}$, $0.5 \% \mathrm{v} / \mathrm{w}$ inoculum $\left(10^{9} \mathrm{CFU} / \mathrm{ml}\right), 30 \% \mathrm{v} / \mathrm{w}$ moisture and $8 \mathrm{pH}$ using $5 \mathrm{~g}$ of wheat bran. Leaving other parameters constant, the only factor being studied is altered, likewise production conditions are optimized one by one; temperature $25-50^{\circ} \mathrm{C}, \mathrm{pH} 6.0-10.0$, inoculums content $0.5-3.0 \% \mathrm{w} / \mathrm{v}$, moisture content $30-80 \%$ and levels of chitinase production are compared. Carbon source supplements such as fish scales, shrimp waste, crab shell powder, glycerol, sucrose, soluble starch; and nitrogen sources such as yeast extract, peptone, tryptone, $\mathrm{NH}_{4} \mathrm{Cl}$, $\left(\mathrm{NH}_{4}\right)_{2} \mathrm{SO}_{4}$ and corn steep liquor are tested for increase in chitinase production. The fermentation conditions are further optimized by RSM-Box-Behnken method and at fully optimized conditions fermentation of a $10 \mathrm{~g}$ batch of wheat bran is carried out through SSF. Software used was STATISTICA Version 10.

\subsection{Purification studies}

Purification procedures are done at $4{ }^{\circ} \mathrm{C}$. Culture broth is centrifuged at $6000 \mathrm{~g}$, lyophilized, mixed in $0.2 \mathrm{M}$ acetate buffer, stirred for an hour, centrifuged at $5000 \mathrm{~g}$ for $15 \mathrm{~min}$, and supernatant is dialyzed against the same buffer. Dialyzed enzyme is subjected to ammonium sulfate precipitation technique at different ranges of concentration from 50 to $80 \%(\mathrm{w} / \mathrm{v})$. This process was conducted at $4{ }^{\circ} \mathrm{C}$ to maintain the biological activity of chitinase. The precipitate is centrifuged, dissolved in acetate buffer and dialyzed against the same buffer. The dialysis bag used was Himedia dialysis membrane-50 with average flat width of $24.26 \mathrm{~mm}, 7.14 \mathrm{~mm}$ radius and an approximate capacity of $1.6 \mathrm{ml} / \mathrm{cm}$. The buffer used for dialysis was changed two to three times for the complete removal of salts. Sodium dodecyl sulfate polyacrylamide gel electrophoresis technique is used to check the molecular weight of the partially purified enzyme. Fractions with enzyme are pooled to measure enzyme activity and protein content. Chitinase activity and protein content were analyzed in supernatant and the pellet $[16,18]$.

\subsection{Characterization studies of partially purified chitinase}

The purified chitinase is tested for its activity and stability at different ranges of temperature, $\mathrm{pH}$ and substrate specificities. 


\subsubsection{Effect of pH on enzyme activity and stability}

Effect of $\mathrm{pH}$ on chitinase activity is tested by incubating the reaction mixture of $1.12 \mu \mathrm{g}$ of chitinase and $0.5 \%$ chitin at different $\mathrm{pH}$ levels ranging 6.5-10 under standard assay conditions. Effect of $\mathrm{pH}$ on chitinase stability is determined by pre-incubating $28 \mu \mathrm{g}$ of chitinase in $100 \mu \mathrm{l}$ of various buffers without substrate at $30^{\circ} \mathrm{C}$, for 24 h. $100 \mathrm{mM}$ each of sodium acetate (pH 4-7) and Tris- $\mathrm{HCl}(\mathrm{pH} 7-9)$ are used as buffers. After pre-incubation, the reaction mixtures are tenfold diluted in a $200 \mu \mathrm{l}$ volume and $40 \mu \mathrm{l}$ of the diluted samples are checked for residual activity under standard assay conditions.

\subsubsection{Effect of temperature on enzymatic activity and stability}

Effect of temperature on chitinase activity is tested by incubating $0.4 \mu \mathrm{g}$ of chitinase with $0.5 \%$ chitin at different temperatures up to $80^{\circ} \mathrm{C}$, at $\mathrm{pH} 8$ for $5 \mathrm{~min}$. Thermal stability of chitinase without substrate is determined by incubating $15 \mu \mathrm{g}$ chitinase in $50 \mathrm{mM}$ sodium acetate buffer at a range of temperatures for half hour at pH 8.5. The residual chitinase activity is measured at standard assay conditions. To measure the thermal stability of chitinase in the presence of substrates, $18 \mu \mathrm{g}$ of chitinase in $50 \mu$ volume is incubated with $0.5 \%$ chitin in $50 \mathrm{mM}$ sodium acetate buffer $\mathrm{pH} 6.5$, at $50^{\circ} \mathrm{C}$ for $30 \mathrm{~min}$. After incubation, the reaction mixtures are diluted 30 -fold in $300 \mu \mathrm{l}$ and $40 \mu \mathrm{l}$ of the diluted samples are taken to determine the residual activity under standard assay conditions.

\subsubsection{Effect of metal ions and compounds on chitinase activity}

The influence of standard metal ions on partially purified chitinase is studied by adding $20 \mathrm{mM}$ metal ions: $\mathrm{K}^{+}$, $\mathrm{Mg}^{2+}, \mathrm{Zn}^{2+}, \mathrm{Fe}^{2+}, \mathrm{Hg}^{2+}, \mathrm{Co}^{2+}, \mathrm{Cu}^{2+}, \mathrm{As}^{4+}, \mathrm{Pb}^{2+}$. The effect of EDTA, SDS and Urea is also tested by adding $10 \mathrm{mM}$ of the chemical to the assay mix and assaying the activity.

\subsubsection{Substrate specificity and enzyme kinetics}

The substrate specificity of the enzyme is tested by reacting it with substrates such as cellulose, carboxymethyl cellulose and swollen chitin. The effect of swollen chitin on the chitinase activity of Citrobacter freundii haritD11 was evaluated by ranging the swollen chitin concentration from 0.5 to $10 \mathrm{mg} / \mathrm{ml}$. A Lineweaver-Burk plot was obtained by plotting $1 / \mathrm{V}$ against $1 / \mathrm{S}$. Kinetic parameters
( $\mathrm{Km}$ and $\left.V_{\max }\right)$ were estimated by linear regression from Lineweaver-Burke plot [24].

\subsubsection{Anticoagulant activity}

Five test tubes with the fabricated $5 \mathrm{mg} / \mathrm{ml}$ fibrin solution are added with partially purified chitinase $(2.8 \mathrm{mg} / \mathrm{ml})$ in the amounts of $0.4 \mathrm{ml}, 0.6 \mathrm{ml}, 0.8 \mathrm{ml}$ and $1 \mathrm{ml}$. After addition, the test tubes were incubated at $40^{\circ} \mathrm{C}$ and assayed for fibrinolysis. Further, the efficacy of the enzyme as an anticoagulant was tested using an artificial blood clot. $3 \mathrm{ml}+3 \mathrm{ml}$ of blood was taken in two 10-ml injection bottles and was left for $5 \mathrm{~min}$ to clot. The first test tube was added with saline and the latter with partially purified chitinase, $1 \mathrm{ml}$ each and observed every $10 \mathrm{~min}$. Moreover, the $C$. freundii haritD11 partially purified chitinase was found to possess anticoagulant activity comparable with the commercially available nattokinase as revealed by the fibrin plate assay [13].

\section{Results and discussion}

\subsection{Optimization studies}

\subsubsection{Solid state fermentation}

Laboratory scale fermentation, with initial conditions of 24-h incubation, $30^{\circ} \mathrm{C}, 5 \% \mathrm{v} / \mathrm{w}$ inoculum, $30 \% \mathrm{v} / \mathrm{w}$ moisture and $8 \mathrm{pH}$ using $5 \mathrm{~g}$ wheat bran, was conducted adopting OVAT approach [23], and at the corrected optimization conditions (Table 1) there was 2.52-fold increased chitinase activity compared to the unoptimized medium (34.11 U/gds). Among all the tested physico-chemical factors, temperature, moisture content and fish chitin content were found to notably influence the chitinase production. The temperature that promoted maximum chitinase yield $(41.87 \mathrm{U} / \mathrm{gds})$ was $35^{\circ} \mathrm{C}$. Temperatures below $30^{\circ} \mathrm{C}$ and above $60^{\circ} \mathrm{C}$ resulted

Table 1 Compendium of physico-chemical parametric optimization, effecting chitinase production from Citrobacter freundii haritD11 during one-variable-at-a-time method

\begin{tabular}{ll}
\hline Parameter/variable & $\begin{array}{l}\text { Chitinase } \\
\text { activity (U/ } \\
\text { gds) }\end{array}$ \\
\hline Incubation time, $24 \mathrm{~h}$ & 34.11 \\
Temperature, $35^{\circ} \mathrm{C}$ & 41.87 \\
Inoculum content, 2\%v/w & 42.33 \\
Moisture content, 60\% $/ \mathrm{w}$ & 56.49 \\
$\mathrm{pH}, 8.0$ & 58.36 \\
Fish scale chitin content, 30\%w/w & 83.57 \\
Peptone content, 2\%w/w & 84.14 \\
\hline
\end{tabular}


in enzyme inhibition [17]. Similar temperatures for chitinase production were reported by other researchers as $30^{\circ} \mathrm{C}$ for Aeromonas [1] and $35^{\circ} \mathrm{C}$ for Citrobacter [23]. Maximum chitinase production was shown at $60 \% \mathrm{v} / \mathrm{w}(56.49 \mathrm{U} / \mathrm{gds})$ moisture content. Too much moisture decreased porosity, and too low decreased solubility of substrate nutrients resulting lowered enzyme activity. Similarly, chitinase production at $65 \% \mathrm{v} / \mathrm{w}$ moisture content using wheat bran has been reported with Trichoderma sps. [27]. Fish scale chitin content of $30 \% \mathrm{w} / \mathrm{w}$ increased chitinase activity $(83.57 \mathrm{U} / \mathrm{gds}$ ) being a naturally rich source of chitin. All experimentations for evaluation of physical parameters were conducted in triplicate, and average values are represented; subsequently, experiments were conducted for optimization of these selected nutrients employing response surface methodology (RSM).

\subsubsection{Response surface methodology}

Box-Behnken method adopting three variables with 15 runs was used for statistical optimization. To perform the 3-factor and 15 -runs analysis, the lowest and highest concentrations of the selected variables were: temperature $30^{\circ} \mathrm{C}$ and $40^{\circ} \mathrm{C}$, moisture content $50 \% \mathrm{v} / \mathrm{w}$ and $70 \% \mathrm{v} / \mathrm{w}$, fish chitin content $20 \% \mathrm{w} / \mathrm{w}$ and $40 \% \mathrm{w} / \mathrm{w}$, respectively. The application of RSM yielded the following regression equation explaining empirical relationship between chitinase yield and test variables in coded units.

$$
\begin{aligned}
Y & =81.56+2.03 X_{1}+5.66 X_{1} X_{1}-0.89 X_{2} \\
& -5.09 X_{2} X_{2}+12.38 X_{3}+3.82 X_{3} X_{3} \\
& -5.99 X_{1} X_{2}-4.33 X_{1} X_{3}-4.33 X_{2} X_{3}
\end{aligned}
$$

where $Y$ is enzyme yield; $X_{1}, X_{2}$ and $X_{3}$ are coded values of temperature, moisture content and fish chitin content, respectively (Table 2). Estimation of regression analysis and ANOVA explains determination coefficient $\left(R^{2}=0.8\right)$ indicating that only very few of the total variations are not explained by the model (Table 3 ). The parity plot displaying clustered points around the diagonal line (Fig. 1) indicates a correlated fit between experimental and predicted values. The smaller $P$ values and good interaction between independent variables confirm significance of each coefficient [26]. The yield values for different concentrations of the variable can also be predicted from the respective response surface plots (Fig. 2), and the maximum predicted values are indicated by the confined surface of the response surface diagram.

The critical levels of the three independent variables examined as predicted from the model are: temperature $34{ }^{\circ} \mathrm{C}$, moisture content $61 \% \mathrm{v} / \mathrm{w}$ and fish chitin content $37.8 \% \mathrm{w} / \mathrm{w}$, and at these conditions predicted chitinase

Table 3 ANOVA; Var.:NewVar4 and 3-level factors $R^{2}=0.8$

\begin{tabular}{lrrlll}
\hline \multicolumn{1}{l}{ SS } & $d f$ & \multicolumn{1}{l}{ MS } & \multicolumn{1}{l}{$F$} & \multicolumn{1}{l}{$p$} \\
\hline (1)Var1 L+Q & 507.009 & 2 & 253.5043 & 1.362331 & 0.337075 \\
(2)Var2 L+Q & 389.364 & 2 & 194.6821 & 1.046221 & 0.417288 \\
$(3) \operatorname{Var}$ L+Q & 1442.847 & 2 & 721.4235 & 3.876926 & 0.096232 \\
$1 * 2$ & 125.328 & 1 & 125.3280 & 0.673512 & 0.449172 \\
$1 * 3$ & 75.169 & 1 & 75.1689 & 0.403957 & 0.552999 \\
$2 * 3$ & 74.736 & 1 & 74.7360 & 0.401631 & 0.554102 \\
Error & 930.407 & 5 & 186.0813 & & \\
Total SS & 3613.642 & 14 & & & \\
\hline
\end{tabular}

Table 2 The Box-Behnken design matrix employed for three independent variables with 15 runs along with observed and predicted chitinase activity values

\begin{tabular}{lllllc}
\hline Run no. & Temperature & Moisture content & Fish chitin content & $\begin{array}{l}\text { Observed chi- } \\
\text { tinase activity (U/ } \\
\text { gds) }\end{array}$ & $\begin{array}{l}\text { Predicted chi- } \\
\text { tinase activity (U/ } \\
\text { gds) }\end{array}$ \\
\hline 1 & 30.00000 & 50.00000 & 30.00000 & 75.6700 & 79.5438 \\
2 & 40.00000 & 50.00000 & 30.00000 & 98.1200 & 94.8112 \\
3 & 30.00000 & 70.00000 & 30.00000 & 85.6400 & 88.9487 \\
4 & 40.00000 & 70.00000 & 30.00000 & 85.7000 & 81.8263 \\
5 & 30.00000 & 60.00000 & 20.00000 & 63.4400 & 49.6950 \\
6 & 40.00000 & 60.00000 & 20.00000 & 69.0000 & 62.4375 \\
7 & 30.00000 & 60.00000 & 40.00000 & 76.5700 & 83.1325 \\
8 & 40.00000 & 60.00000 & 40.00000 & 64.7900 & 78.5350 \\
9 & 35.00000 & 50.00000 & 20.00000 & 64.2800 & 74.1513 \\
10 & 35.00000 & 70.00000 & 20.00000 & 70.5700 & 81.0063 \\
11 & 35.00000 & 50.00000 & 40.00000 & 118.0000 & 107.5638 \\
12 & 35.00000 & 70.00000 & 40.00000 & 107.0000 & 97.1288 \\
13 & 35.00000 & 60.00000 & 30.00000 & 86.4100 & 87.4267 \\
14 & 35.00000 & 60.00000 & 30.00000 & 88.2900 & 87.4267 \\
15 & 35.00000 & 60.00000 & 30.00000 & 87.5800 & 87.4267 \\
\hline
\end{tabular}




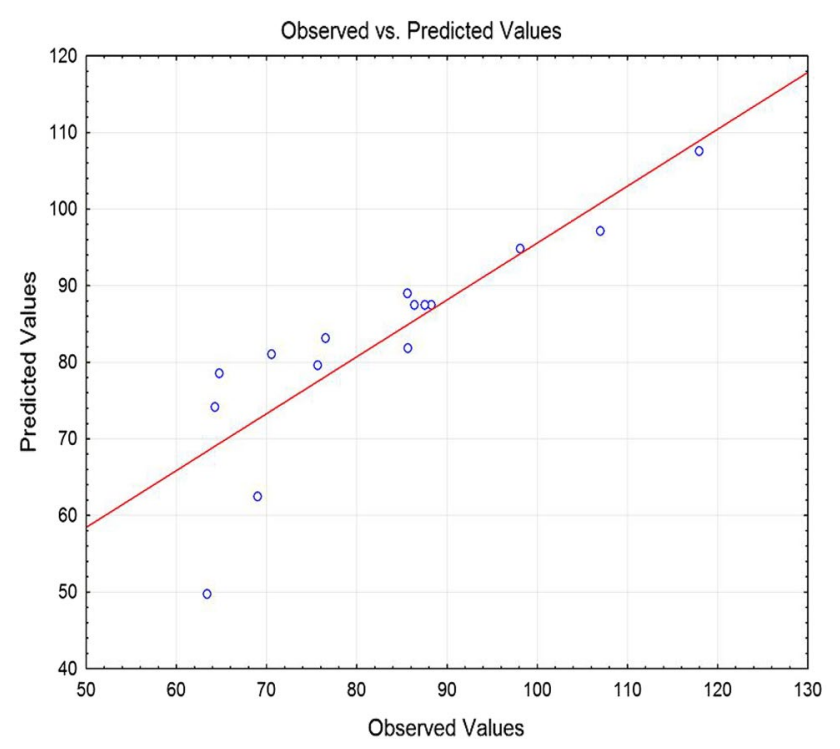

Fig. 1 The parity plot between the experimental and predicted values of chitinase activity presenting the accuracy of the model

activity was $92.117 \mathrm{U} / \mathrm{gds}$. A verification experiment at the critical conditions confirmed that the experimental value (94.3 $\mathrm{U} / \mathrm{gds}$ ) was similar to the value predicted substantiating both validity and effectiveness of the model. Statistically optimized culture conditions using Box-Behnken method showed augmented chitinase production of 1.12-fold that of basic optimization (one-variable-at-atime-approach) culture conditions ( $84.14 \mathrm{U} / \mathrm{gds}$ ). A similar report following RSM optimization with 1.1-fold increase in enzyme activity for chitinase production from Parapeneopsis hardwickii (spear shrimp) exoskeleton by solid state fermentation was reported [23].

\subsection{Purification and characterization studies}

The crude chitinase extract was partially purified by ammonium sulfate precipitation and dialysis. Chitinase in the culture filtrate was extracted by $70 \%$ ammonium sulfate precipitation followed by dialysis and DEAE Sephadex A-50. The partially purified chitinase is shown as a single band in the SDS-PAGE Zymogram with molecular weight of $62.5 \mathrm{kDa}$ (Fig. 3). The molecular weights of chitinases from marine bacteria are mainly around $60 \mathrm{kDa}$. Similarly, $64 \mathrm{kDa}$ molecular weight of Xanthomonas sp. strain $A K$ chitinase was reported by Yamaoka et al. [24, 32]. Chitinase was purified 3.9 -fold with $37 \%$ yield and specific activity of $53.41 \mathrm{U} / \mathrm{mg}$ protein from $20 \mathrm{~g}$ of wheat bran supplemented with fish chitin (Table 4). Chitinase of Stenotrophomonas maltophilia isolated from rhizospheric soil was purified 2.4-fold through Sephadex gel filtration and has 50-55 kDa molecular weight [28].

\subsubsection{Effect of $\mathrm{pH}$ and temperature on enzyme activity and stability}

Partially purified chitinase showed optimum activity at 8.5 $\mathrm{pH}$. A sharp decrease in enzyme activity was shown at $\mathrm{pH}$ values higher than 10 or lower than 7.5 showing increased activity at alkaline conditions. The enzyme was stable at $7.5-10 \mathrm{pH}$ range for $1 \mathrm{~h}$ at $4{ }^{\circ} \mathrm{C}$ in various buffers $(100 \mathrm{mM}$ each of sodium acetate $(\mathrm{pH} \mathrm{4-7)}$ and Tris- $\mathrm{HCl}(\mathrm{pH} 7-9)$; Correspondingly, chitinase from Alternaria infectoria was stable at alkaline $\mathrm{pH}[8]$ but some bacterial chitinases were found stable at acidic $\mathrm{pH}[9,10]$.

The optimum temperature for chitinase was recorded at $50{ }^{\circ} \mathrm{C}$; likewise $50^{\circ} \mathrm{C}$ has been reported for Aspergillus terreus [9], Paenibacillus pasadenensis CS0611 and Escherichia coli [31]. Chitinase maintained $80 \%$ stability between $45^{\circ} \mathrm{C}$ and $60^{\circ} \mathrm{C}$ in $50 \mathrm{mM}$ sodium acetate buffer, lower or higher temperatures lead to activity inhibition. At these conditions, chitinase was tested for its salt tolerance at various concentrations of sodium chloride and showed $85 \%$ activity at $8 \%$ and was completely stable at $8 \%$ for an hour. Chitinases with alkaline $\mathrm{pH}$ optima and stability have applications in biological control of insect pests and can be used in synergism with other biocontrol agents.

\subsubsection{Influence of metal ions and EDTA, SDS, Urea on enzyme activity}

The influence of various metal ions on the chitinase activity is shown in Table 5. There was a relative increase in activity with $\mathrm{Na}^{+}(66 \%), \mathrm{K}^{+}(31 \%), \mathrm{Mg}^{2+}(40 \%), \mathrm{Mn}^{2+}(65 \%)$, $\mathrm{Fe}^{2+}(32 \%), \mathrm{Cu}^{2+}(13 \%)$, Urea (28\%), $\mathrm{NaCl}(80 \%)$, while relatively decreased chitinase activity was detected with EDTA (13\%), SDS (39\%), $\mathrm{Hg}^{2+}(11 \%)$, and ethyl-acetimidate (20\%). A similar kind of effect of metal ions and other compounds has also been recorded for chitinase from Bacillus thuringiensis subsp. kurstaki HBK-51 where $\mathrm{Ni}^{2+}(32 \%), \mathrm{K}^{+}(44 \%)$ and $\mathrm{Cu}^{2+}(56 \%)$ increased the enzyme activity, while EDTA (7\%), SDS (7\%), $\mathrm{Hg}^{2+}(11 \%)$ and ethyl-acetimidate (20\%) decreased the activity of the enzyme [15]. Bacillus sp. R2 purified chitinase when subjected to the effect of metal ions, chemical agents on its activity showed that $\mathrm{K}^{+}, \mathrm{Mn}^{2+}$, $\mathrm{Na}^{+}, \mathrm{Mg}^{2+}$ and $\mathrm{Ca}^{2+}$ stimulated chitinase activity by $2,4,7,15$ and $21 \%$, respectively, whereas $\mathrm{Cu}^{2+}, \mathrm{Fe}^{2+}, \mathrm{Zn}^{2+}, \mathrm{Ag}^{+}$and $\mathrm{Hg}^{2+}$ inhibited the enzyme [7].

\subsubsection{Substrate specificity and enzyme kinetics}

The partially purified chitinase showed highest substrate specificity toward swollen chitin among chitin, swollen chitin, cellulose and carboxy methyl cellulose; hence, the kinetics of enzyme were studied with swollen chitin. Michaelis-Menten constants were determined 
Fig. 2 Contour plots between temperature (Var 1), moisture content (Var 2), fish chitin content (Var 3) and the corresponding chitinase activity. The different colored bars shown in the right side scale represent the various levels of chitinase activity accordingly, and as the color gets darker, the response increases. The response is at its highest at the darkest region of the graph
A

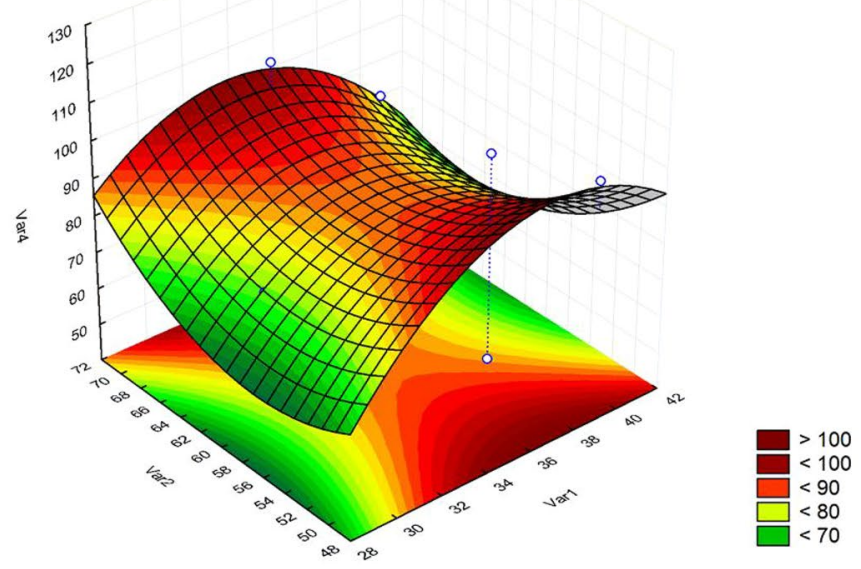

B

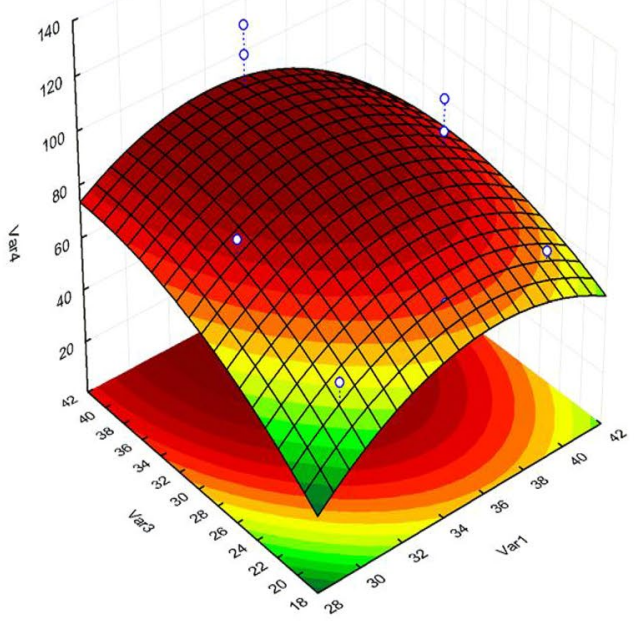

C

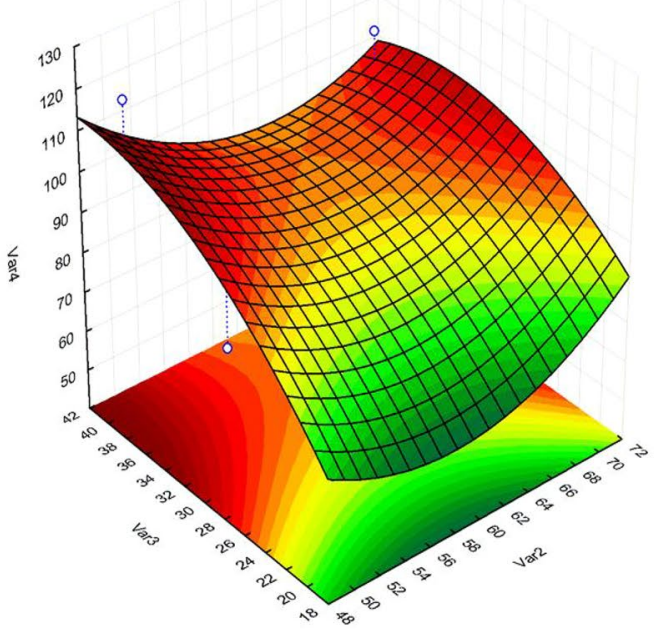




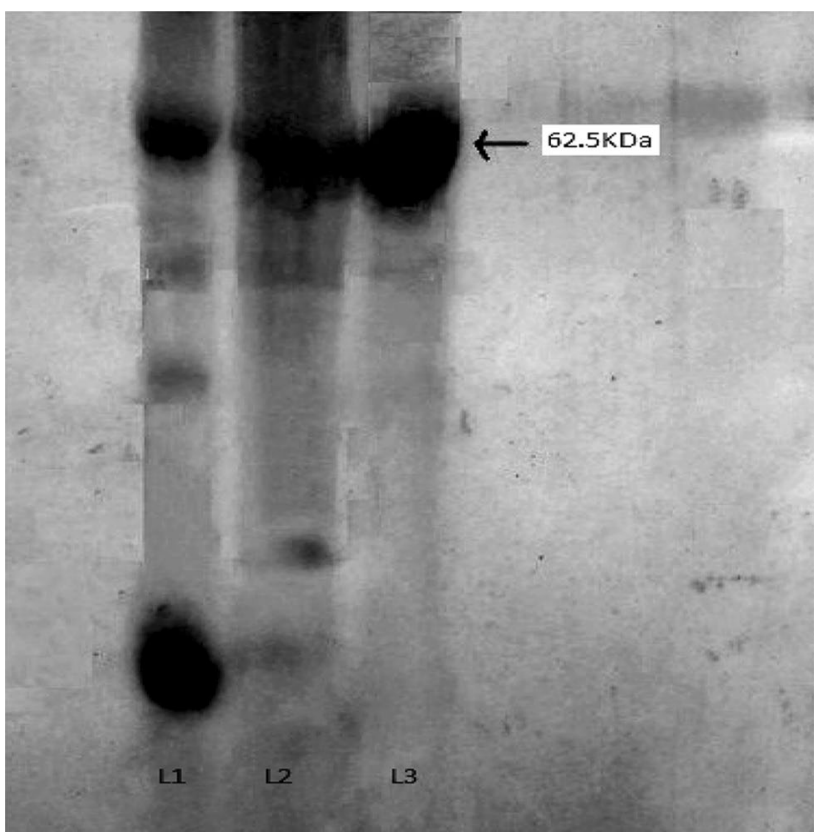

Fig. 3 SDS PAGE result (L1 marker lane; L2, L3 enzyme sample lanes). L1 is the lane with the molecular markers ladder, L2 shows the lane of bands with dialyzed chitinase, and L3 is the lane showing single band of partially purified chitinase subjected to Sephadex DEAE A-50 gel filtration

using Lineweaver-Burke plot designed to calculate reaction velocities at each substrate concentration. From the Michaelis-Menten kinetics and the Lineweaver-Burke plot (Fig. 4), the $\mathrm{Km}$ value of the $C$. freundii haritD11 partially purified chitinase for swollen chitin is $8.11 \mathrm{mg} / \mathrm{ml}$ with a $V_{\max }$ of $2.43 \mathrm{mmol} \mathrm{h}^{-1} \mathrm{ml}^{-1}$. Similarly, the value of $\mathrm{Km}$ for Serratia marcescens B4A partially purified chitinase was $8.3 \mathrm{mg} / \mathrm{ml}$ with swollen chitin as a substrate [34]. The higher the velocity of the enzyme, the faster the rate of catalysis; hence, lower the $\mathrm{Km}$ value, the enzyme is a favorable biocatalyst. However, the Bacillus sp. BG11 exhibited $\mathrm{Km}$ value as high as $12 \mathrm{mg} / \mathrm{ml}$ with swollen chitin have been reported [4].

\subsubsection{Anticoagulant activity}

Among various test tubes with the fabricated $5 \mathrm{mg} / \mathrm{ml}$ fibrin solution incubated with partially purified chitinase,
Table 5 Effect of metal ion or other chemical compounds on the activity of chitinase

\begin{tabular}{lc}
\hline $\begin{array}{l}\text { Metal ion/com- } \\
\text { pound }\end{array}$ & $\begin{array}{l}\text { Relative } \\
\text { activity }\end{array}$ \\
\hline None & 100 \\
$\mathrm{Na}+$ & 166 \\
$\mathrm{~K}+$ & 131 \\
$\mathrm{Mg}^{2+}$ & 140 \\
$\mathrm{Mn}^{2+}$ & 165 \\
$\mathrm{Fe}^{2+}$ & 132 \\
$\mathrm{Hg}^{2+}$ & 73 \\
$\mathrm{Co}^{2+}$ & 31 \\
$\mathrm{Cu}^{2+}$ & 113 \\
$\mathrm{As}^{4+}$ & 26 \\
$\mathrm{~Pb}^{2+}$ & 64 \\
$\mathrm{Zn}^{2+}$ & 90 \\
$\mathrm{Urea}$ & 128 \\
$\mathrm{SDS}$ & 61 \\
$\mathrm{EDTA}$ & 87 \\
$\mathrm{NaCl}$ & 180 \\
\hline
\end{tabular}

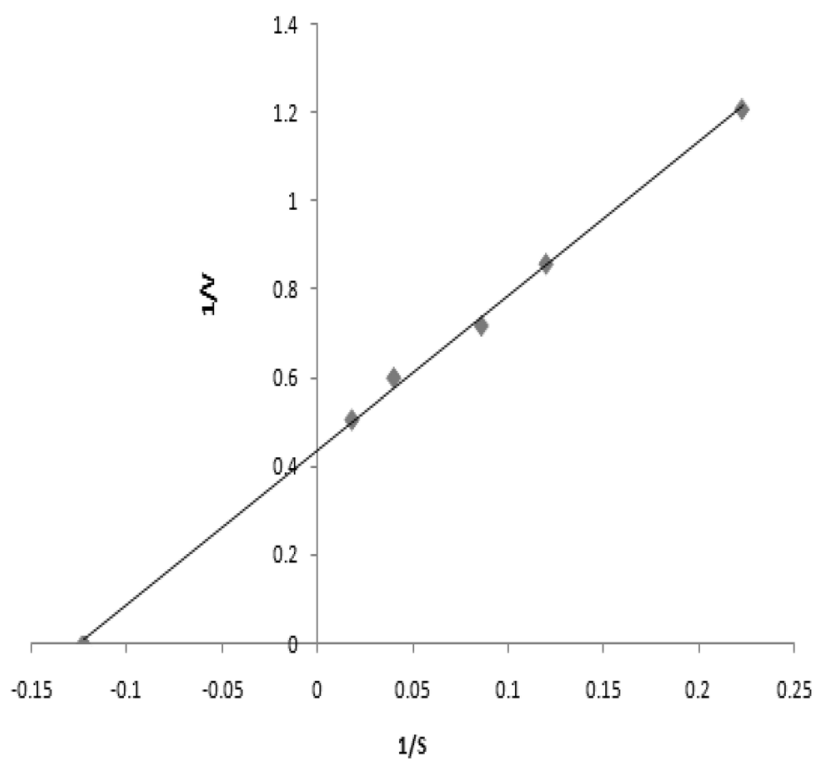

Fig. 4 Lineweaver-Burke plot
Table 4 Steps in purification of chitinase

\begin{tabular}{llllc}
\hline Purification step & Total activity $(\mathrm{U})$ & $\begin{array}{l}\text { Specific activity } \\
(\mathrm{U} / \mathrm{mg})\end{array}$ & $\begin{array}{l}\text { Folds of purifica- } \\
\text { tion }\end{array}$ & \% Yield \\
\hline Culture supernatant & 3813 & 13.7 & 1 & 100 \\
$\left(\mathrm{NH}_{4}\right)_{2} \mathrm{SO}_{4}$ ppt & 2917 & 24.66 & 1.8 & 78 \\
Dialysis & 2249 & 43.84 & 3.2 & 59 \\
Sephadex DEAE A-50 & 1410 & 53.41 & 3.9 & 37 \\
\hline
\end{tabular}



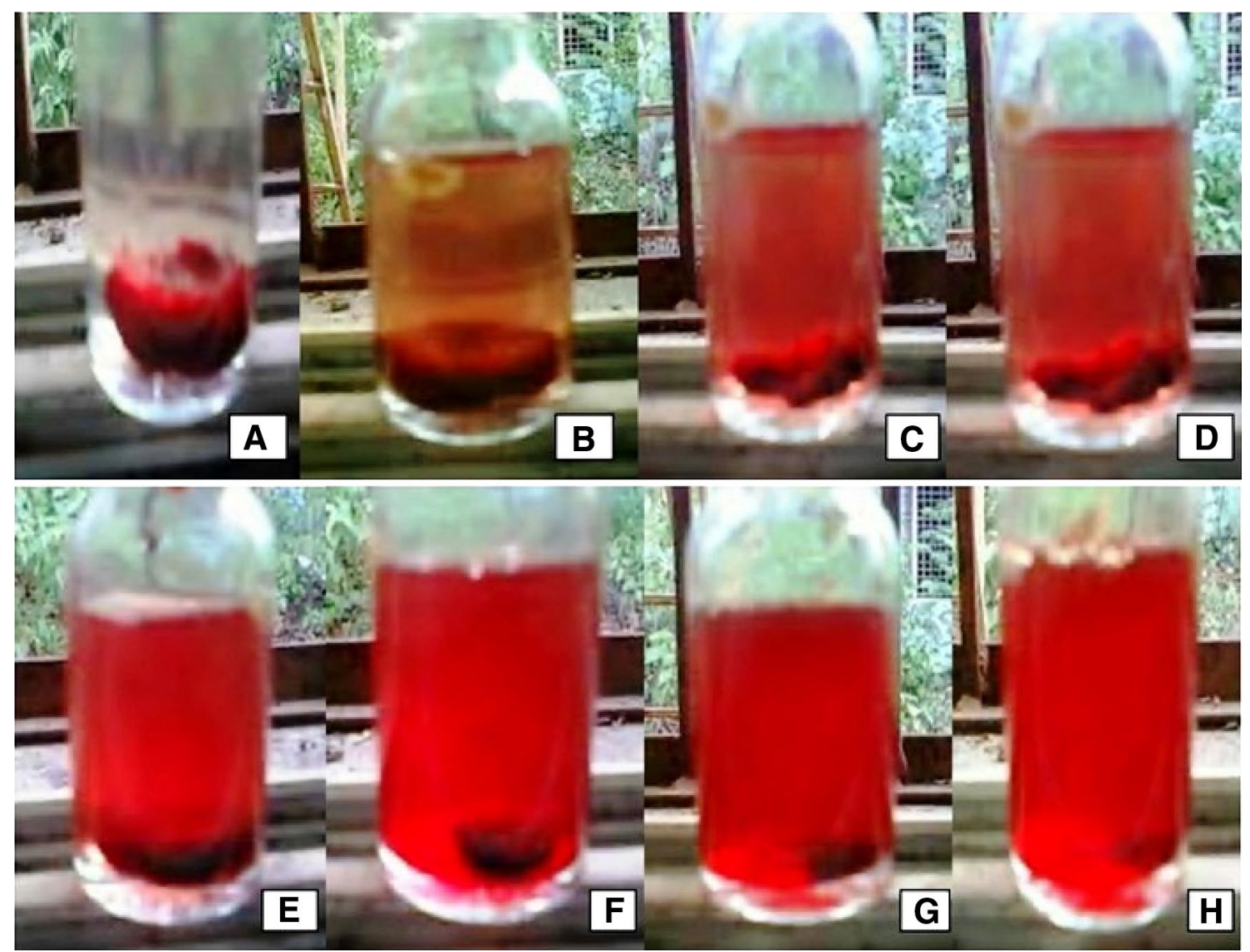

Fig. 5 Evaluation of the fibrinolysis using artificial blood clot (a clot with saline; b clot with chitinase; c clot with chitinase after $10 \mathrm{~min}$; d clot with chitinase after 20 min; e clot with chitinase after 30 min;

maximum fibrinolysis was shown by the $1 \mathrm{ml}$ amount. Further, the efficacy of the purified enzyme as an anticoagulant was tested with an artificial blood clot and apparently complete lysis was observed after 60 min (Fig. 5). Moreover, the $C$. freundii haritD11 partially purified chitinase was found to possess fibrinolytic activity comparable with the commercially available nattokinase where the radial hydrolysis zone around the chitinase well was $1.62 \mathrm{~mm}$ and $1.7 \mathrm{~mm}$ for the latter. There are reports stating that chitin derivatives and chitosanases have been used for clinical applications as wound healer, blood anticoagulants and hemostatic materials [35]. However, this is the first report stating that chitinase of marine Citrobacter freundii haritD11 can be used as a potent anticoagulation agent due its ability to lyse a blood clot effectively within an hour. Hence, chitinases can also be used as commercial blot clot dissolving agents or hemolytic agents that find applications in myriad medical sectors. f clot with chitinase after 40 min; $\mathbf{g}$ clot with chitinase after 50 min; h clot with partially purified chitinase after $60 \mathrm{~min}$ )

\section{Conclusion}

There are numerous reports on the production of chitinase from microorganisms such as fungi, actinomycetes, bacteria and plants; however, there is no single evident report on chitinase production from Citrobacter freundii fermenting wheat bran supplemented with fish scales (at a monitored ratio). Our research has established the superior production of chitinase through supplementation of fish chitin with wheat bran improving the quality of an assorted substrate for solid state fermentation, contributing to cost-cutting strategies and production of chitinase with anticoagulant activity. From an industrial perspective, chitinase of Citrobacter freundii str. nov. haritD11 has many beneficial characteristics such as high productivity, high specific activity, easy purification, relatively high halotolerance and thermostability, and as an anticoagulant in its partially purified form. In a nutshell, this is the first report to date elucidating the production of chitinase using an assorted ratio of wheat bran and fish scale chitin with Citrobacter freundii haritD11, its partial purification, 
characterization and application as a potential anticoagulant agent.

Funding The funding was provided by Andhra University (Grant No. Andhra University College of Engineering Institutional PhD Research Scholar, 2010-2015).

\section{Compliance with ethical standards}

Conflict of interest The authors declare that there is no conflict of interest.

\section{References}

1. Al-Ahmadi KJ, Yazdi MT, Najafi MF, Shahverdi AR (2008) Optimization of medium and cultivation conditions for chitinase production by newly isolated Aeromonas sp. Biotechnology 7:266-272

2. Almalki MA (2018) Solid state fermentation of agro-residues for the production of amylase from Bacillus subtilis for industrial applications. Int J Curr Microbiol App Sci 7(3):1341-1348

3. Bahrami M, Ahmad H (2018) Penaeus vannamei protease activating mechanism of sulfhydryl reducing compounds. Int J Biol Macromol 112:1131-1137

4. Bhushan B, Hoondal GS (1998) Isolation, purification, and properties of a thermostable chitinase from an alkalophilic Bacillus sp. BG-11. Biotechnol Lett 20:157-159

5. Binod P, Pusztahelyi T, Viviana N, Chandran S, George S, István P, Pandey A (2005) Production and purification of extracellular chitinases from Penicillium aculeatum NRRL 2129 under solidstate fermentation. Enzyme Microbial Technol 36:880-887. https ://doi.org/10.1016/j.enzmictec.2004.12.031

6. Box GEP, Hunter WG, Hunter JS (1978) Statistics for experiments. Wiley, New York, pp 291-334

7. Cheba BA, Zaghloul TI, EL-Massry ML, EL-Aahdy AR (2016) Effect of metal ions, chemical agents, and organic solvent on Bacillus sp. R2 chitinase activity. Procedia Technol 22:465-470

8. Chiriboga NOG, Rorrer GL (2017) Control of chitin nanofiber production by the lipid-producing diatom Cyclotella sp. through fed-batch addition of dissolved silicon and nitrate in a bubblecolumn photobioreactor. Biotechnol Prog 33(2):407-415

9. El-Shora H, Khalaf SA, El-Sheshtawi SAH (2017) Biochemical Characteristics of Immobilized Chitinase from Alternaria infectoria. Microbiol Res J Int 22(1):1-10

10. Farag AM, Abd-Elnabey HM, Ibrahim HAH, El-Shenawy M (2016) Purification, characterization and antimicrobial activity of chitinase from marine-derived Aspergillus terreus. Egypt J Aquat Res 42(2):185-192

11. Ghanem KM, Al-Garni SM, Al-Makishah NH (2010) Statistical optimization of cultural conditions for chitinase production from fish scales waste by Aspergillus terreus. Afr J Biotechnol 9:5135-5146

12. Heravi KM, Rigi G, Arjomand MR, Rostami A, Ahmadian G (2015) An alternative bacterial expression system using Bacillus pumilus SG2 chitinase promoter. Iran J Biotechnol 13(4):17-24

13. Jespersen J, Astrup T (1983) A study of the fibrin plate assay of fibrinolytic agents. Pathophysiol Haemost Thromb 13:301-315. https://doi.org/10.1159/000214769

14. Kumari S, Kumar Rath P (2014) Extraction and characterization of chitin and chitosan from (Labeo rohit) fish scales. Procedia Mater Sci 6:482-489. https://doi.org/10.1016/j.mspro.2014.07.062

15. Kuzu SB, Güvenmez HK, Denizci AA (2012) Production of a thermostable and alkaline chitinase by Bacillus thuringiensis subsp. kurstaki Strain HBK-51. Biotechnol Res Int 2012, Article ID 135498,6

16. Lowry OH, Rosebrough NJ, Farr AL, Randall RJ (1951) Protein measurement with the folin phenol reagent. J Biol Chem 193:267-275

17. Meier KK, Jones SM, Kaper T, Hansson H, Koetsier MJ, Karkehabadi S, Solomon El, Sandgren M, Kelemen B (2018) Oxygen activation by Cu LPMOs in recalcitrant carbohydrate polysaccharide conversion to monomer sugars. Chem Rev 118(5):2593-2635

18. Meruvu $\mathrm{H}$ (2017) Catalytic profile and Amylolytic studies of toluene tolerant Enterococcus faecalis str. nov. mercadA7. Arab J Sci Eng 42(4):1517-1527

19. Meruvu H, Vangalapati M (2011) Critical studies on physico-chemical parameters for the production of protease through SSF with Bacillus subtilis NCIM 2724 using black gram husk as substrate. Biosci Biotechnol Res Asia 8(1):179-184

20. Meruvu H, Vangalapati M (2011) Optimization of protease production from husk of Vigna mungo by Bacillus subtilis NCIM 2724 using statistical experimental design. Rasayan J Chem 4(1):159-164

21. Meruvu H, Donthireddy SRR (2012) Chitinous seafood waste for production of a fungicidal enzyme. Int J Innov Res Dev 1:108-111

22. Meruvu H, Donthireddy SRR (2013) Biochemical and molecular taxonomy of chitinolytic Citrobacter freundii haritD11 isolated from Indian marine environment. J Pharm Bio Sci 4:1168-1175

23. Meruvu H, Donthireddy SRR (2014) Optimization studies for chitinase production from Parapeneopsis hardwickii exoskeleton by solid state fermentation using novel Citrobacter freundii haritD11. Arab J Sci Eng 39:5297-5306

24. Meruvu H, Donthireddy SRR (2014) Purification and characterization of an antifungal chitinase from Citrobacter freundii str. nov. haritD11. Appl Biochem Biotechnol 172:196-205

25. Miller GL (1959) Use of dinitrosalicylic acid reagent for determination of reducing sugar. Anal Biochem 3:426-428

26. Mourabet $M$, El Rhilassi A, El Boujaady H, Bennani-Ziatni M, Taitai A (2017) Use of response surface methodology for optimization of fluoride adsorption in an aqueous solution by Brushite. Arab J Chem 10(2):S3292-S3302

27. Nampoothiri KM, Baiju TV, Sandhya C, Sabu A, Szakacs G, Pandey A (2004) Process optimization for antifungal chitinase production by Trichoderma harzianum. Process Biochem 39:1583-1590

28. Sohel S, Sonal W, Riyaz S, Rishu T, Arvind G (2018) Production, purification and kinetics of chitinase of Stenotrophomonas maltophilia isolated from rhizospheric soil. Indian J Exp Biol 56:274-278

29. Sousa D, Venancio A, Belo I, Salgado JM (2018) Mediterranean agro-industrial wastes as valuable substrates for lignocellulolytic enzymes and protein production by solid-state fermentation. J Sci Food Agric. https://doi.org/10.1002/jsfa.9063

30. Tang WJ, Fernandez J, Sohn JJ, Amemiya CT (2015) Chitin is endogenously produced in vertebrates. Curr Biol 25(7):897-900

31. Thimote SS, Glogauer A, Faoro H, de Souza EM, Huergo LF, Moerschbacher BM, Pedrosa FO (2017) A broad pH range and processive chitinase from a metagenome library. Braz J Med Biol Res 50(1):e5658

32. Yamaoka H, Hayashi H, Karita S, Kimura T, Sakka K, Ohmiya K (1999) J Biosci Bioeng 88:328-330

33. Yazid AN, Raquel B, Dimitrios K, Antoni S (2017) Solid-state fermentation as a novel paradigm for organic waste valorisation: a review. Sustainability 9(2):224

34. Zarei M, Aminzadeh S, Zolgharnein H, Safahieh A, Dalir M, Noghabi $\mathrm{K}$ (2011) Characterization of a chitinase with antifungal activity from a native Serratia. Braz J Microbiol 42:1017-1029

35. Zhu X, Zhou Y, Feng J (2007) Analysis of both chitinase and chitosanase produced by Sphingomonas $s p$. CJ-5. J Zhejiang Univ Sci B 8(11):831-838. https://doi.org/10.1631/jzus.2007.b0831 